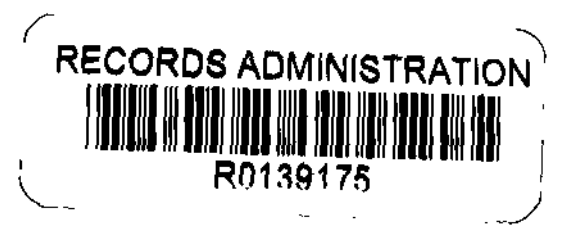

DP-1613

\title{
ENVIRONMENTAL EFFECTS OF A TRITIUM RELEASE FROM THE SAVANNAH RIVER PLANT
}

\author{
ALFRED J. GARRETT \\ ELMER L. WILHITE \\ MELVIN R. BUCKNER
}

SRL

RECORD SOPY

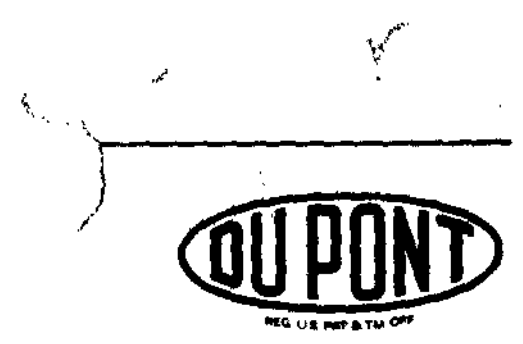

E. I. du Pont de Nemours \& Co. Savannah River Laboratory Aiken, SC 29808 
This report was prepared by E. I, du Pont de Nemours and Company (Du Pont) for the United States Department of Energy under Contract DE-ACO9-76SfO0001 and is an account of work performed under that Contract. Neither the United States, the United States Department of Energy nor Du Pont, nor any of their employees, makes any warranty, express or implied, or assumes any legal liability or responsibility for the accuracy, completeness, or usefulness of any information, apperatus, product, or process disclosed herein, or represents that its use will not infringe privately owned rights. Reference herein to any process, or service by trade name, mark, manufacturer, or otherwise does not mecessarily constitute or imply endorsement, recommendation, or favoring of same by Du Pont or by the United States Government or any agency thereof. The views and opinions of authors expressed herein do not necessarily state or reflect those of the United States Government or any agency thereof.

Printed in the United States of America

Available from

National Technical Information Service

U. S. Department of Commerce

5286 Port Royal Rosd

Springfield, Virginia 22161

Price: Printed Copy A03; Microfich AOI 
DP-1613

Distribution Category: UC-11

\section{ENVIRONMENTAL EFFECTS OF A TRITIUM RELEASE FROM THE SAVANNAH RIVER PLANT}

Alfred J. Garrett

Elmer L. Wilhite

Melvin R. Buckner

Approved by

T. V. Crawford, Research Manager

Environmental Sciences Division

Publication Date: November 1981

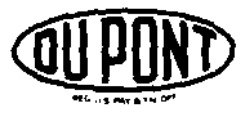

E. 1. du Pont de Nemours \& Co.

Savannah River Laboratory

Aiken, SC 29808

PAEPARÉD FOR THE U. S. DEPARTMENT OF ENERGY UNDER CONTRACT DE.ACOO-76SAOODO1 


\section{ABSTRACT}

The environmental impact of a small HTo release from the Savannah River Plant tritium operations was assessed by using both predictive and measurement techniques. Predictions of the onsite and offsite consequences by the WIND and ARAC emergency response systems and the JEREMIAH environmental computational system agreed closely with activity levels determined from environmental samples.

The maximum dose to a hypothetical iadividual at the SRP boundary as a result of this release was estimated to be 0.3 mrem. The maxinum dose observed by urinalysis of offsite individuals in the release trajectory was $0.2 \mathrm{mrem}$. Since a person receives about $190 \mathrm{mrem} / \mathrm{yr}$ from natural background, medical $\mathrm{x}$-rays and miscellaneous radiation sources, the dose consequence of this release was not significant. 


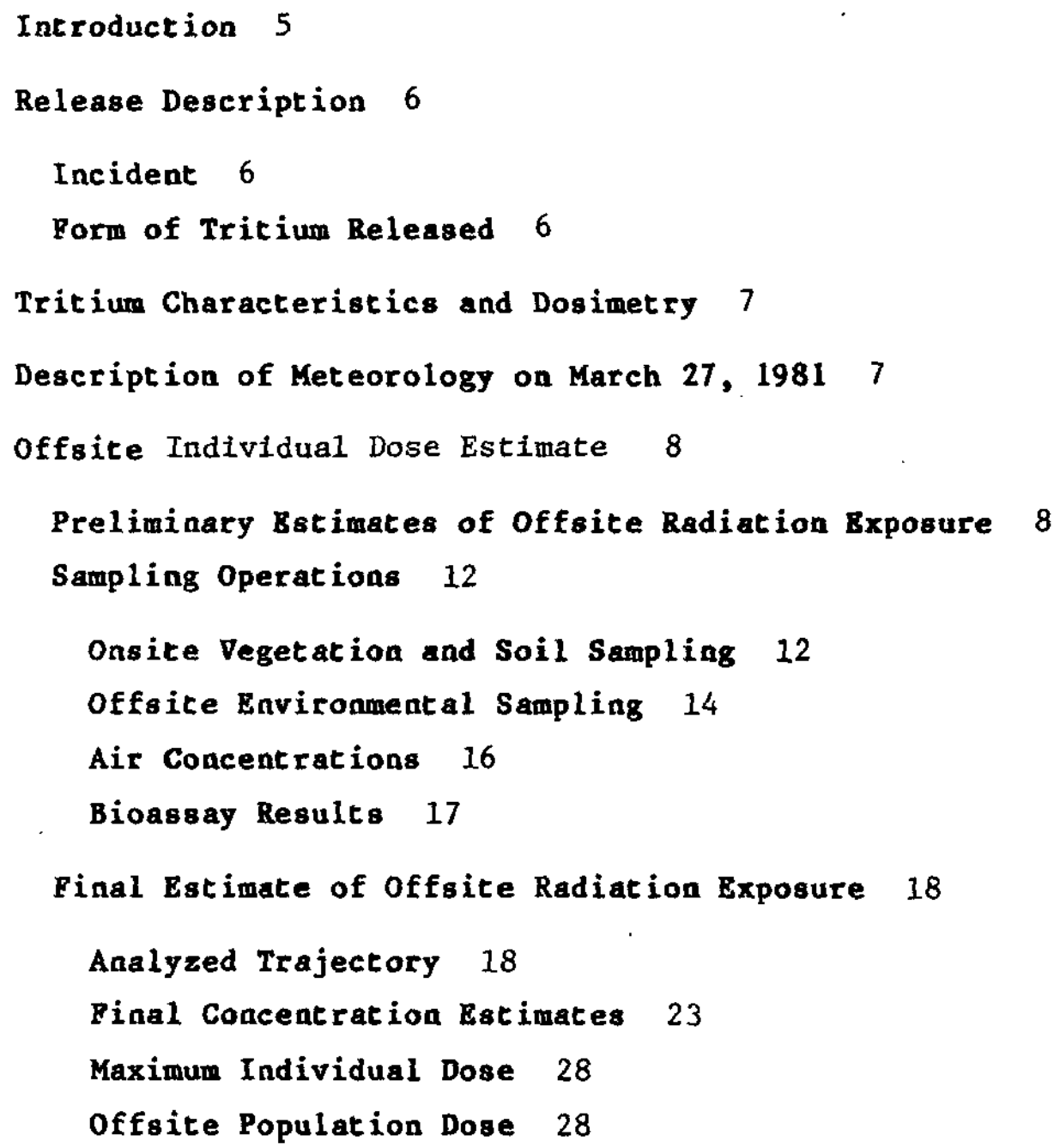

A. Urinalysis Data 32

B. Calculation of Atmospheric Tritium Concentration From Tritium Levels in Vegeration, Soil, and Surface Water 37 
ENVIRONMENTAL EFPECTS OF A TRITIUM RELEASR FROM THB

SAVANNAH RIVER PLANT

\section{INTRODUCTION}

Tritium is one of the major products of the Savannah River Plant (SRP). It is produced by irradiation of lithium targets in the SRP production reactors. After irradiation, the targets are sent to a tritium processing facility where the tritium is extracted, purified, and packaged. The tritium facility is in the center of the plantsite, approximately $13 \mathrm{~km}$ from the nearest public zone. Normal releases of tritium from the reactors and tritium-processing facilities to the atmosphere result from small leaks and infrequent exposure of normally closed systems to ventilation air. A brief discussion of SRP tritium releases and their causes is given in Reference 1 ; a more extensive review of tritium processes in Federal facilities is provided in Reference 2.

On March 27, 1981, a small amount of tritiated water* was inadvertently released from the tritium-processing facility during a routine maintenance operation. This report describes the environmental effects of this release both on the SRP site and offsite. Also, the operation of the WIND (Wind INformation and Display) emergency response system during the incident is discussed, and the predicted and diagnosed behavior of the tritiun plume is compared with tritium concentrations deduced from air, vegetation, soil, and bioassay samples.

* HTO and HT will be used in this report to represent tritium in any of the possible oxide or molecular forms (i.e. HTO, DTO, and $\mathrm{T}_{2} \mathrm{O}$ or $\mathrm{HT}$, DT, and $\mathrm{T}_{2}$ respectively. 


\section{RELEASE DESCRIPTION}

\section{Incident}

The release occurred at 9:45 a.m. EDT* on March 27, 1981, when a pipe in a process hood was disassembled during a routine maintenance procedure. Approximately $20 \mathrm{~m} 1$ of tritiated water leaked from the pipe, evaporated, and was discharged from the tritium facility stack. Tritium releases are continuously monitored at SRP by a Kanne chamber (an ionization chamber through which an aliquot of the stack air is pumped). This monitor indicated a release of $32,934 \mathrm{Ci}$ (or approximately 33,000 Ci) of tritium. The incremental releases during the release period are as follows:

\begin{tabular}{lllr}
$\begin{array}{l}\text { Starting } \\
\text { Time, a.m. }\end{array}$ & $\begin{array}{l}\text { Duration, } \\
\text { min }\end{array}$ & $\begin{array}{l}\text { Curies } \\
\text { Released }\end{array}$ \\
\cline { 1 - 1 } $9: 45$ & 30 & 2,794 \\
$10: 15$ & 30 & 23,750 \\
$10: 45$ & 30 & 4,886 \\
$11: 15$ & 30 & 1,410 \\
$11: 45$ & 30 & 96 \\
& Total & 32,934
\end{tabular}

* Eastern daylight time.

\section{Form of Tritium Released}

Analysis of the tritium forms sampler, used in addition to the Kanne Chamber to monitor the stack discharge, indicated that more than $99 \%$ of the release was tritium oxide. While the Kanne instrument measures the total tritium released, the tritium forms sampler determines the tritium gas and the tritium oxide components of the release. Tritium forms samplers were also used by the environmental sampling teams dispatched to monitor the movement of the release. These measurements also showed that more than $99 \%$ of the tritium was in the oxide form.

There were other indications that a major fraction of the tritium was in the oxide form. The stack Kanne monitor indicated slow decreases in release rates follawing the peaks. The slopes were characteristic of previous releases that resulted from tritiated water evaporation. In addition, there was the visual evidence of a sma11 quantity of liquid that leaked from the disassembled pipe. 


\section{TRITIUM CHARACTERISTICS AND DOSIMETRY}

Tritium is a radioactive isotope of hydrogen (H) with an atomic mass of 3 and a radiological half-life of $12.33 \mathrm{yr}$. The maximum energy of the beta particle emitted during decay is $0.0186 \mathrm{MeV}$; the average energy is about $0.006 \mathrm{MeV}$.

Some tritium is released to the atmosphere during normal SRP operations, both as an elemental gas (HT) and as tritium oxide (HTO). Both forms are odorless, tasteless, colorless, and readily dispersed in air; they will enter into the same chemical (and biological) reactions as hydrogen or water vapor.

The low-energy beta particle emitted by tritium during decay will penetcate human $t$ issue only $0.013 \mathrm{~cm}$. As an elemental gas, tritium constitutes relatively little hazard, because the weak beta particle is completely attenuated by the inert external skin layer (epidermis) and because only $0.004 \%$ of elemental $=r i t i u m$ inhaled is converted to the oxide and retained in the body. ${ }^{3}$

Almost all of the oxide form (water vapor) that is inhaled is absorbed in the lungs and enters the body water pool, and all body tissues are exposed. In addizion, almost as much tritium oxide is absorbed through the skin as is absorbed from inhalation. ${ }^{4}$

The average biological half-life of tritium in the body of SRP employees is 9.6 days. $^{5}$ Values as high as 19 days have been reported. 3 The value used by the International Commission on Radiological Protection ${ }^{6}$ for calculating concentration guides is ten days, and this value is used for dosimetry calculations in this report.

\section{DESCRIPTION OF METEOROLOGY ON MARCH 27, 1981}

Weather over the southeastern United States on the morning of March 27 was dominated by a weak cell of high pressure centered over the Georgia-Florida border. Skies over South Carolina were sunny during the day, with scattered fair weather cumulus forming in the afternoon. Temperatures over the state were about $25^{\circ} \mathrm{C}$ during the afternoon.

As shown in Figure la, winds over Georgia and South Carolina were uniformly from the west-southwest with a velocity of about 5 $\mathrm{m} / \mathrm{sec}$ at an elevation of $10 \mathrm{~m}$, and about $10 \mathrm{~m} / \mathrm{s}$ at $1500 \mathrm{~m}$. The 10$m$ winds increased to a mid-day maximum of 6 to $7 \mathrm{~m} / \mathrm{s}$, aided by downwat transfer of momentum through the deep mixed-1ayer. In the early afternoon, a seabreeze developed along the Georgia coast near Saint Simon's Island (see Figure lb). The seabreeze moved in at Charleston later in the afternoon, but its penetration inland apparently was never great enough to affect the movement of the tritium. The seabreeze died out by early evening. 
To the north, in Virginia and Kentucky, a cold front was moving south. This cold front traveled south slowly during the day and crossed the northern border of South Carolina between 6:00 p.m. and 7:00 p.m. as shown in Figure 1c. This cold front dominated surface flow during the early morning hours of March 28 , as shown in Figure 1d; however, the winds at elevations higher than a few hundred meters remained west to northwest.

\section{OFFSITE INDIVIDUAL DOSE ESTIMATE}

\section{Preliminary Estimates of Offsite Radiation Exposure}

Following notification at 11:15 a.m. on March 27 ESD personnel immediately activated the WIND System Emergency Response Codes and generated forecasts of the movement and dispersion of the tritium. These initial trajectory forecasts guided HP Department and ESD field crews as they took air, soil, and vegetation samples. An early trajectory forecast at 11:47 a.m. (Figure 2a) predicted tritium movement toward the east-northeast, with the position 12 hours after release south of Florence, South Carolina. An updated forecast that was generated at $2: 23 \mathrm{p} . \mathrm{m}$. (Figure 2b) predicted a similar trajectory, except at large downwind distances, where a turn to due east was expected. The updated trajectory made use of a new set of forecast winds that were transmitted to SRP by the National Weather Service (NWS). The NWS forecast winds were adjusted to reflect local influences on weather with a technique known as Model Output Statistics (MOS). The NWS developed the MOS technique because the large-scale atmospheric models used by the NWS for weather prediction cannot include local terrain features, such as individual hills or river valleys. (The MOS technique has been applied to the SRP for use in emergency response predictions.) Hourly wind observations from surface stations in eastern South Carolina were compared to the forecast winds as they came in. These wind observations verified the forecast and reduced the uncertainty in positioning the field crews at large downwind distances.

Table 1 shows predicted plume centerline concentrations and doses* at the plant boundary for the $11: 47$ a.m. and $2: 23$ p.m. ca1culations. The predictions from the 11:47 a.m. run were higher, because the estimated number of curies released was higher at that time.

* The WIND Emergency Response Code uses a dose factor of $0.143 \mathrm{Rem}-\mathrm{m}^{3} / \mathrm{C} i-\mathrm{sec}$ for HTO. 


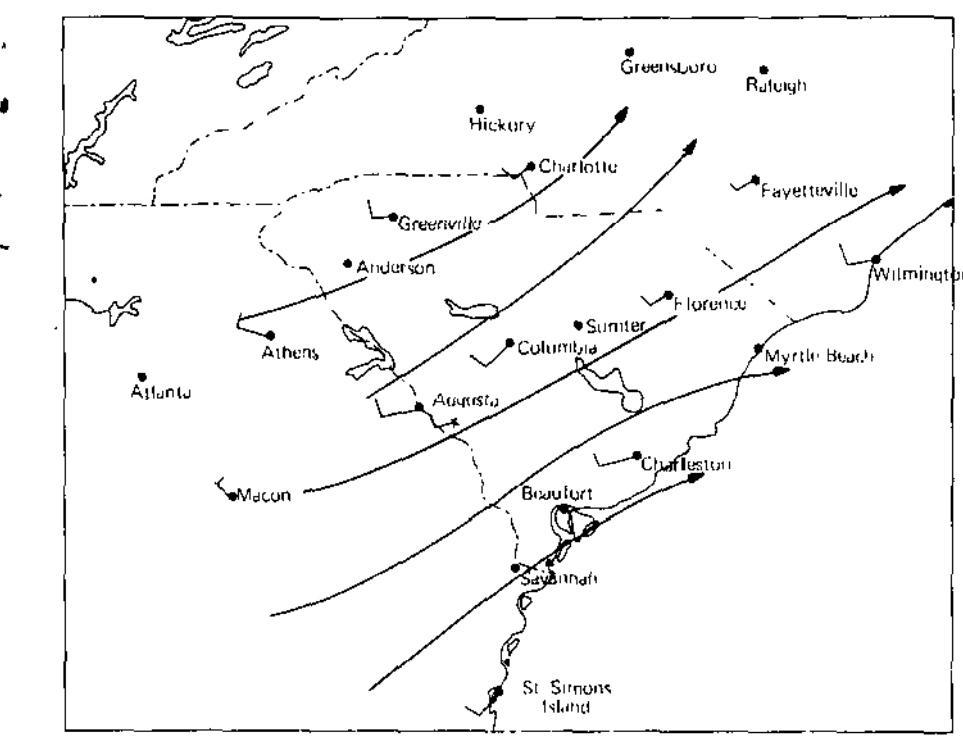

a. March 27, 10:00 a.m.

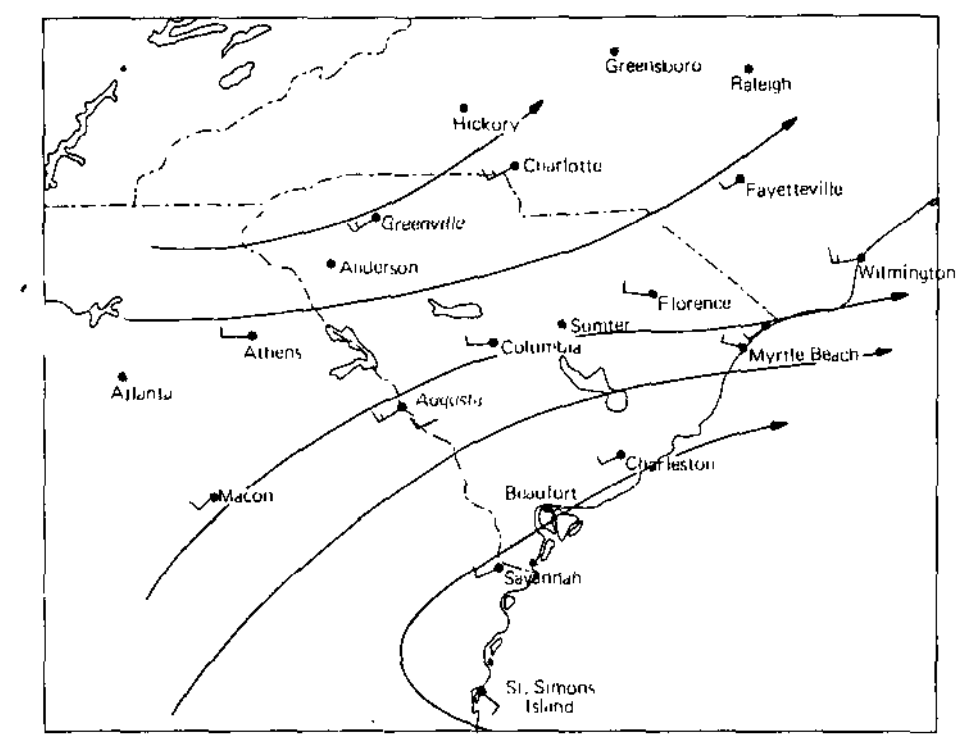

b. March 27, 2:00 p.m.

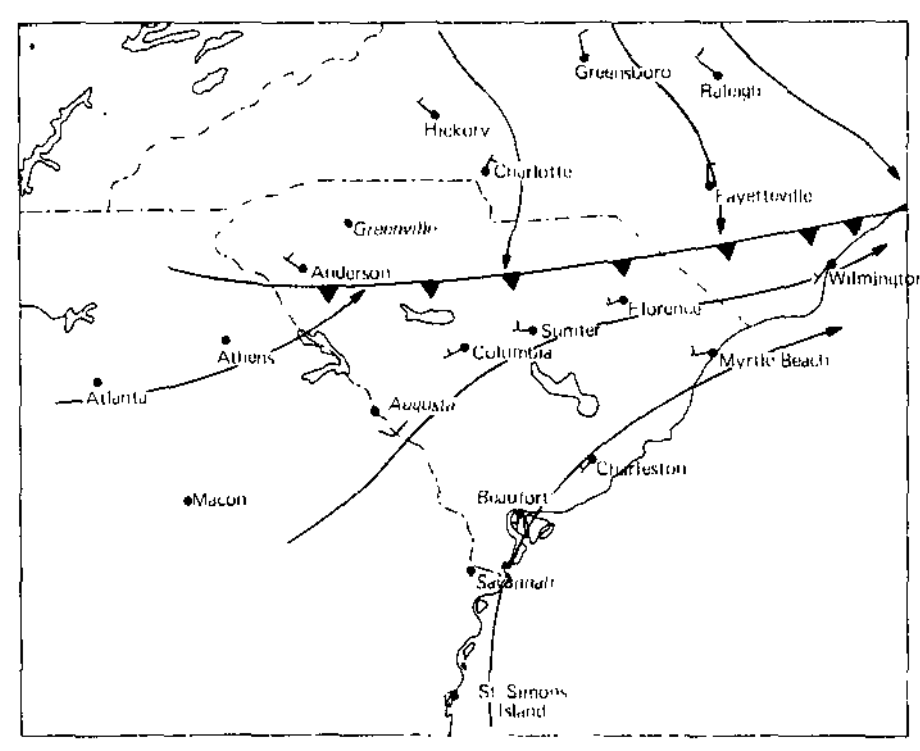

c. March 27, 7:00 p.m.

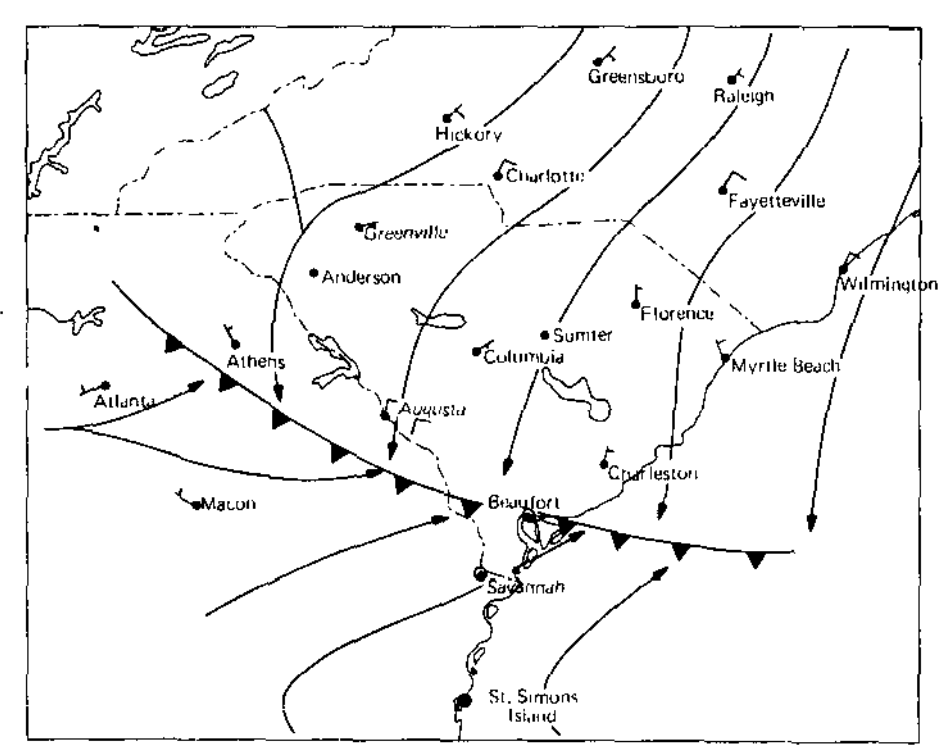

d. March 28, 2:00 a.m.

FIGURE 1. Surface Winda for March 27-28, 1981 


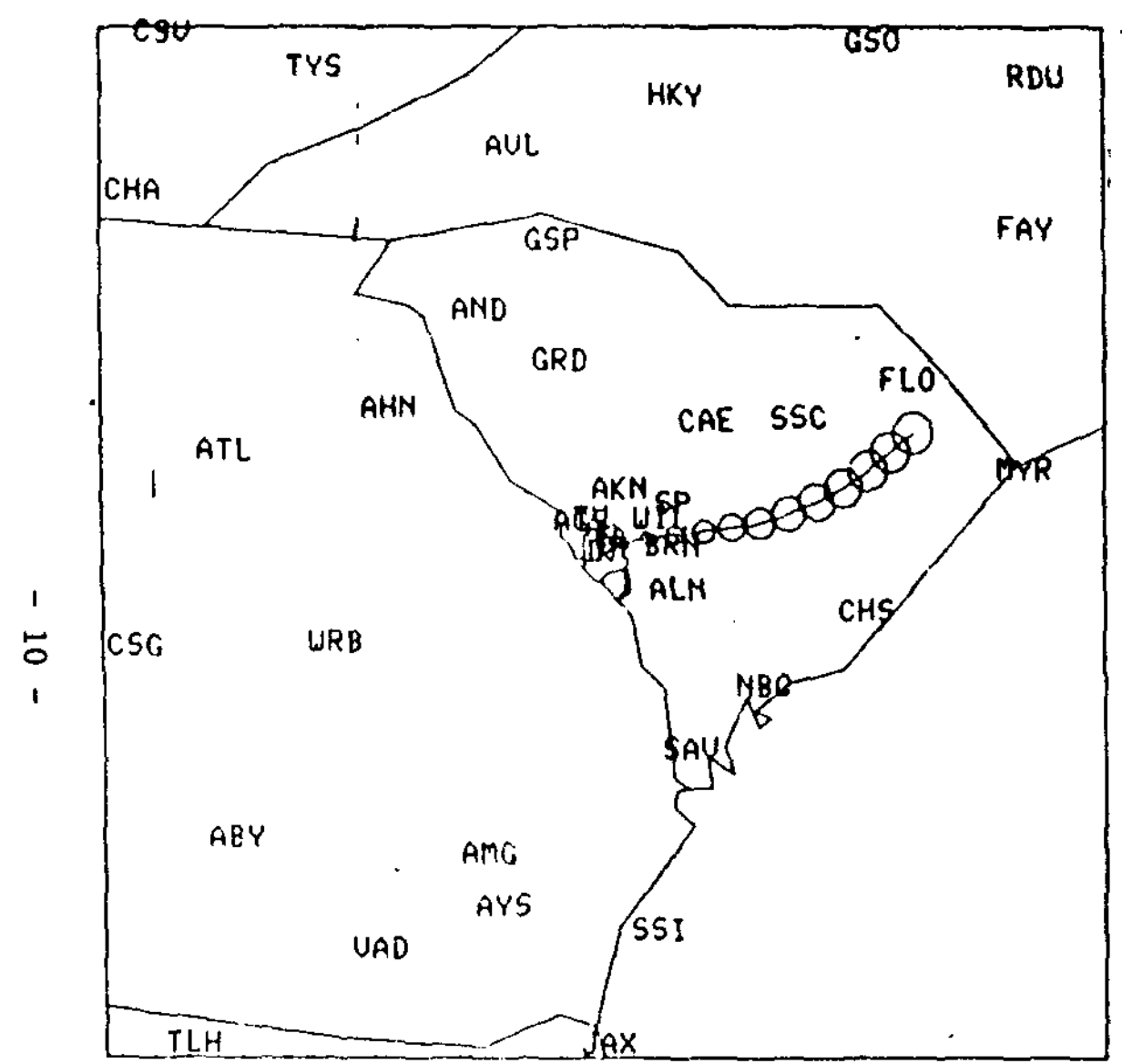

2a. Early Forecast Trajectory of Tritium Movement

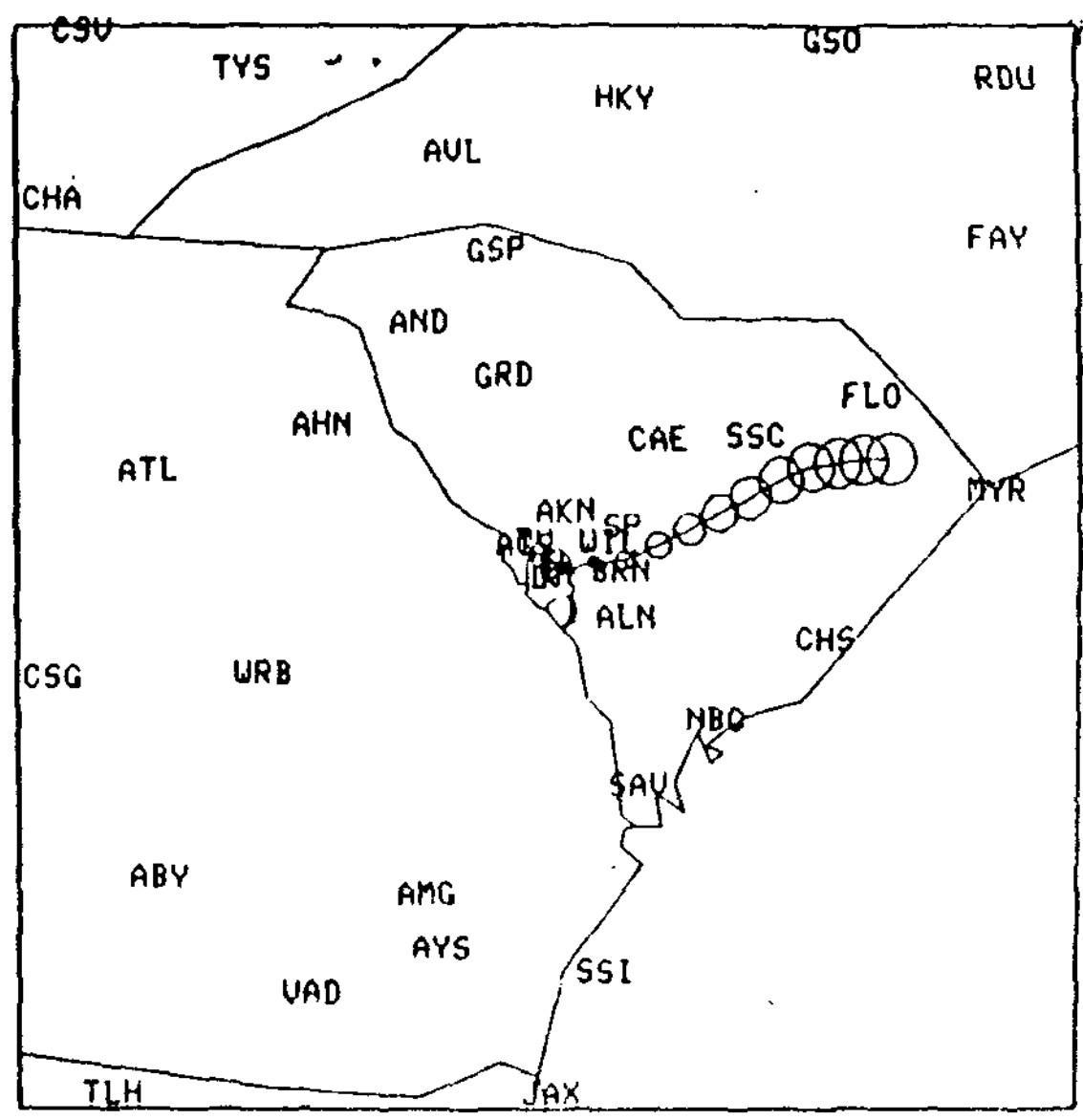

2b. Updated Forecast Trajectory of Tritium Movement

FIGURE 2. WIND System Predicted Trajectories 
TABLE 1

Preliminary Predictions of Plant Boundary Doses and Concentrations Based on 11:47 a.m. and 2:23 p.m. Runs of Rmergency Response Code

Time of Calculation on March 27, 1981

11:27 a.m. 2:23 p.m.

Dose at Plant Boundary, mrem

$3.5 * \quad 2.5 *$

Concentrations at Plant Boundary $\mathrm{pCi} / \mathrm{m}^{3}$

$4 \times 10^{6} \quad 2.25 \times 10^{6}$

Estimated Size of Release, Ci

$40,000 \quad 33,000$

Estimated Duration of Release,

minutes

90

120

* Estimates based on additional meteorological data available on the day after the release indicated a maximum individual dose at the Plant boundary of 0.3 mrem.

In addition to the WIND system, SRP is linked to the Atmospheric Release Advisory Capability (ARAC) of the Lawrence Livermore National Laboratory (LLNL). Under DOE (Department of Energy) funding, ESD is evaluating this capability for use in response to accidents at nuclear facilities located throughout the United States. Meteorological data from the SRP tower network are transtaitted to LLNL every four hours for use in response to an SRP emergency. As a test of the ability of ARAC to respond to an SRP emergency, ESD meteorologists contacted ARAC operators at $11: 45$ a.m. on March 27 and the ARAC 3-dimensional emergency response code (ADPIC) was run for the tritium release. There were initial difficulties due to malfunctioning wind speed instrumentation at H-Area, which were overcome by using nearby F-Area winds. 
The WIND system contains a quality assurance code that checks the data and replaces any suspicious data with averages from surrounding towers. The first ADPIC calculations were transmitted to SRP at 2:45 p.m., with plant boundary dose estimates of around 0.5 mrem based on F-Area winds. The difference between the dose prediction by ARAC and WIND was partly due to the differences between $\mathrm{H}$ - and F-Area meteorology (see Table 2). The salient differences between the meteorology from the two locations are the larger diffusivities implied by the $\sigma_{a}$ and $\sigma_{e}$ values at $F$ Area. The $\sigma_{a}$ value for F-Area is a full stability class higher, and the $\sigma_{e}$ value is two stability classes higher. The discrepancies between the $\mathrm{F}^{-}$and H-Area measurements will be discussed further in Section VI.C.2. Another reason for the smaller ARAC dose estimates is the $60 \%$ smaller dose factor used in ADPIC.

\section{TABLE 2}

\section{F- and H-Area Meteorological Parameters for the Hour Ending at $10: 30$ on March 27, 1981 .}

Wind Speed, $\mathrm{m} / \mathrm{s}$

$\sigma_{a}$

$\sigma_{\mathrm{e}}$

* Estimated by quality assurance code.
Wind Direction, Degrees from north

\begin{tabular}{ll} 
Area & \\
\hline 3.7 & $\frac{\mathrm{H}}{4.2^{*}}$ \\
253 & 259 \\
19.9 & 14.3 \\
18.9 & 8.5
\end{tabular}

\section{Sampling Operations}

\section{Onsite Vegetation and Soil Sampling}

Samples of loblolly pine needles, pine litrer and mineral soil were collected around 1:00 p.m., March 27, near the site boundary along SRP Road 8 and SC Highway 278 . These locations are roughly perpendicular to the trajectory of the release as shown in Figure 3. Additional vegetation, litter, and soil samples were collected on March 28, 29, and 30 from locations which had elevated tritium levels. A sample of water was also taken from a small puddle next to Road 8 near the center of the release path about $13 \mathrm{~km}$ from $H$ Area. 


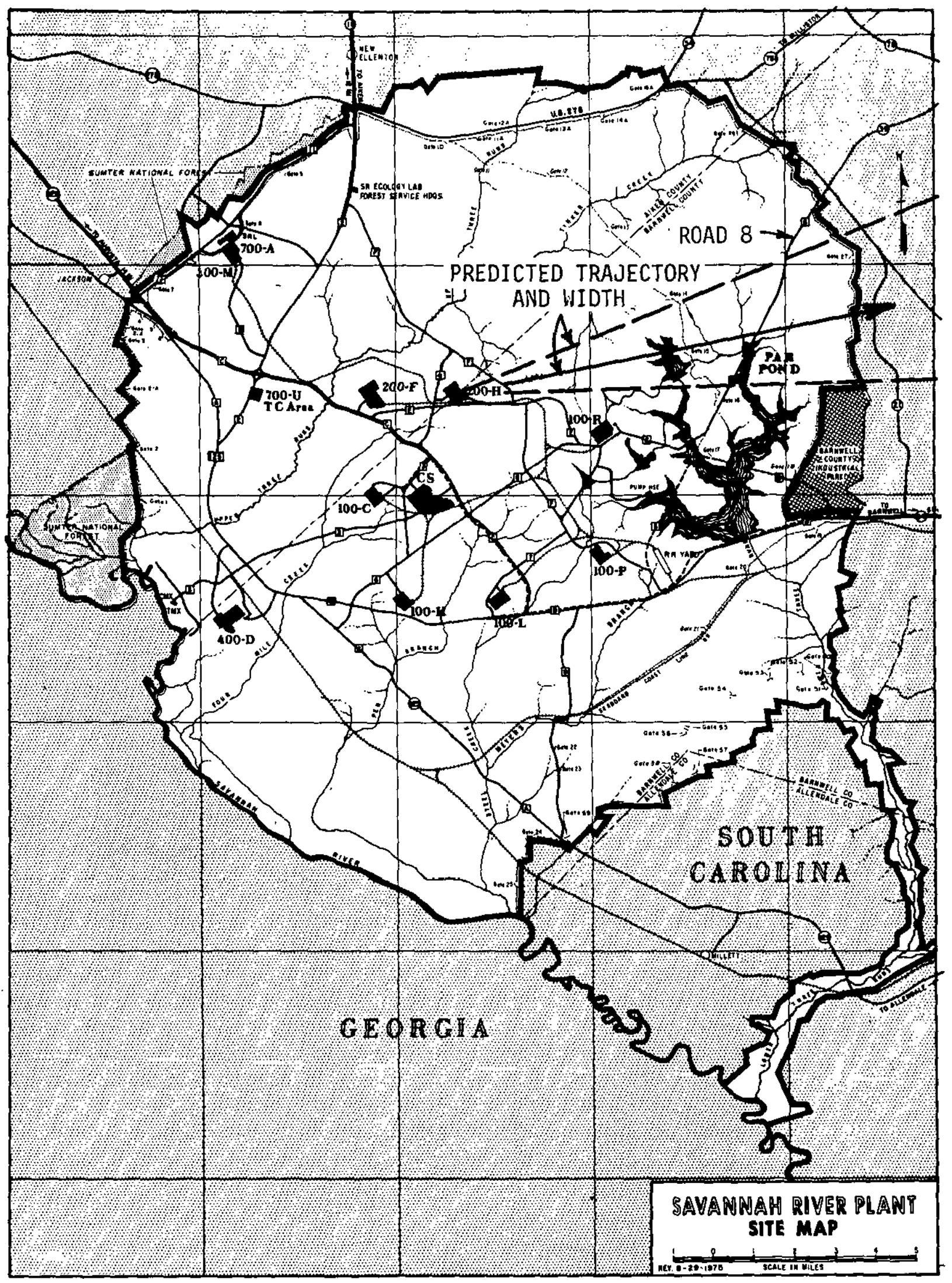

FIGURE 3. Onsite Vegetation and Soil Sampling Locations 
Tritium levels in vegetation water are shown in Table 3 . The highest level recorded was $\sim 5000 \mathrm{pCi} / \mathrm{mL}$. Tritium levels in pine litter water were also elevated; but the maximum level, 2800 $\mathrm{pCi} / \mathrm{mL}$, was less than that found in living pine needles. The location and extent of tritium in litter was similar to that found in vegetation. Surface water taken from a shallow puddle $\left(\begin{array}{lll}1-5 & \mathrm{~cm}\end{array}\right)$ near the center of the cloud trajectory had a tritium concentration of $300 \mathrm{pCi} / \mathrm{ml}$. Mineral soil samples were all near background ( $20 \mathrm{pCi} / \mathrm{mL})$.

Resampling after 24 and $48 \mathrm{hr}$ showed that the tritium in living vegetation disappeared very rapidly. After 24 hours, all pine needle samples were close to background tritium levels. Pine litter, on the other hand, retained the tritium for a longer period. After 48 hours, water from litter samples still contained up to $250 \mathrm{pCi} / \mathrm{mL}$. However, rainfall on March 30 reduced all tritium levels to the background range, and sampling was discontinued.

\section{TABLE 3}

Onsite Vegetation and Soil Sampling Data March 27, 1981 AT 1:00 p.m.

\section{Location}

Road 8, Point 0

Road 8, Point 1

Road 8, Point 2

Road 8, Point 3

Road 8, Point 4

Road 8, Point 5

Road 8, Point 6

Road 8, Point 7

US 278, Point 8
Activity, $\mathrm{pCi} / \mathrm{mL}$

42.4

28.6

76.1

4858.0

4564.0

2114.0

268.0

278.0

55.8

\section{Offsite Environmental Sampling}

An extensive environmental monitoring program was initiated after the release to provide an overall assessment of contamination to the environment. Over 400 samples, including vegetation, soil, surface water, food crops, milk, and air were collected from March 27 through April 2. Elevated concentrations of tritium were observed in environmental samples collected in a northeasterly direction from the plant perimeter extending out to distances beyond Orangeburg, South Carolina. Major routes monitored and locations of the maximum concentrations measured in food crops, soil, vegetation, milk, and water are shown in Figure 4. Tritium levels in all offsite environmental samples are summarized in Table 4. 


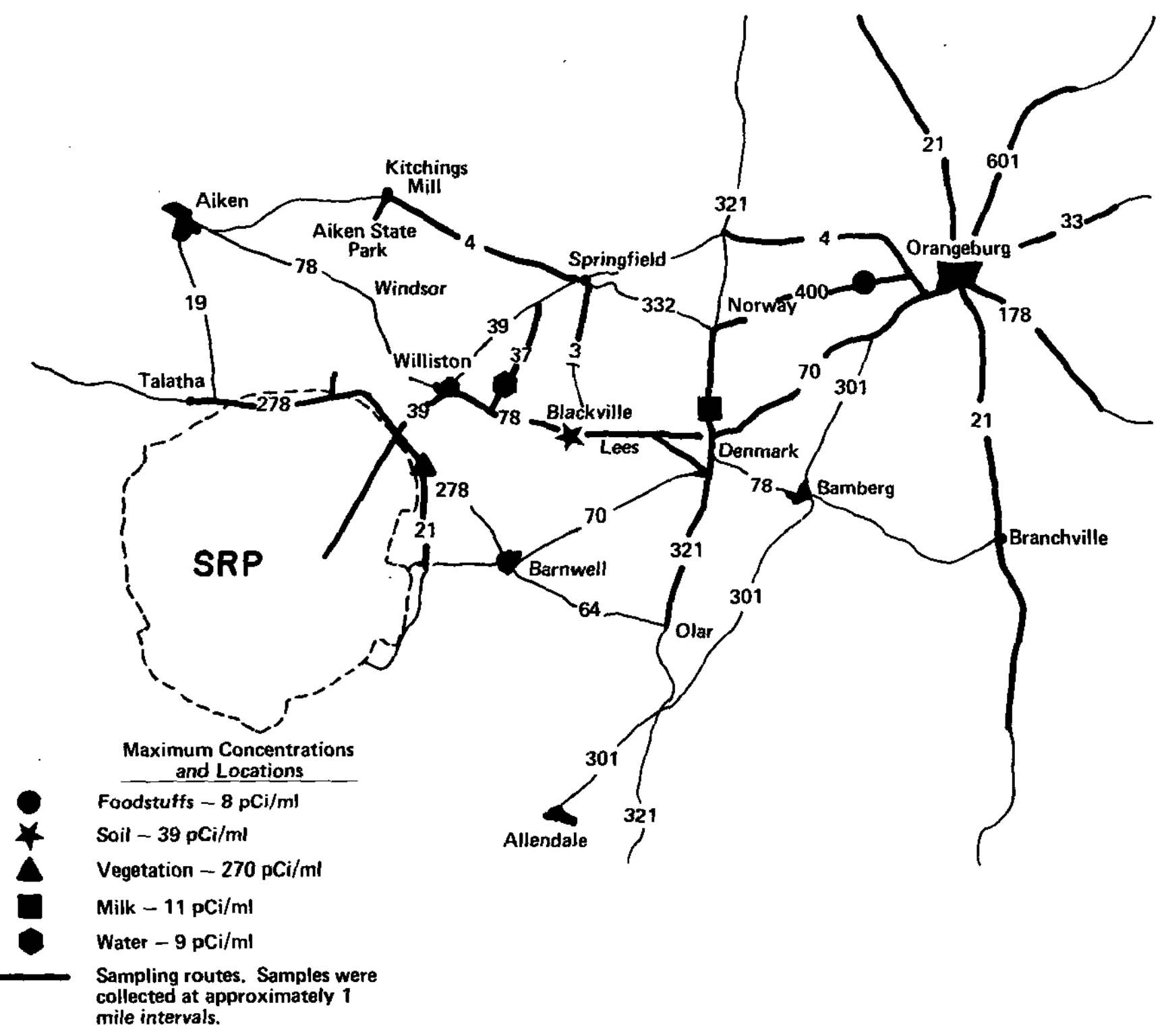

FIGURE 4. Environmental Sampling Routes Following the Tritium Release on March 27, 1981 
TABLE 4

\section{Tritium Levels in Environmental Samples After the Relesse on March 27, 1981}

\begin{tabular}{|c|c|c|c|c|}
\hline \multirow{2}{*}{$\begin{array}{l}\text { Type } \\
\text { Sample }\end{array}$} & \multirow{2}{*}{$\begin{array}{l}\text { No. of } \\
\text { Samples }\end{array}$} & \multicolumn{3}{|c|}{ Concentration, $\mathrm{pCi} / \mathrm{mL}$} \\
\hline & & Maximum & Mínimum & Average \\
\hline Foodstuff & 17 & 8 & $<2$ & 2 \\
\hline Soil & 27 & 39 & 1 & 6 \\
\hline Vegetation & 79 & 270 & 1 & 21 \\
\hline Milk & 8 & 11 & $<2$ & 5 \\
\hline Water & 22 & 9 & $<2$ & 2 \\
\hline
\end{tabular}

Atmospheric moisture collected at routine monitoring stations near or within the plume during a two-week period ending March 27 showed no elevated levels of tritium. These samples would not be expected to reflect the tritum release because of the length of the collection period (2 weeks) and the low sample volumes (100 cc/min).

\section{Air Concentrations}

Two ESD sampling teams were dispatched by 12:00 noon to collect atmospheric samples with high sensitivity tritium forms samplers along the forecast plume trajectory. The sampler separates and concentrates the oxide (HTO) and the elemental form of tritium (HT) from $1500 \mathrm{~L}$ of air during a 30-min period with a sensitivity less than background $\left(1.8 \mathrm{pCi} / \mathrm{m}^{3}\right)$. Twelve samples were collected between 1:00 p.m. and 9:00 p.m. at locations based upon periodically updated WIND system predictions of the tritium movement relayed to the sampling teams by phone.

The atmospheric concentrations and compositions observed along the forecast trajectory are listed in Table 5. The highest atmo6 pheric tritium oxide concentration observed was approximately $80,000 \mathrm{pCi} / \mathrm{m}^{3}$ collected $0.8 \mathrm{~km}$ south of Norway, South Carolina, $51 \mathrm{~km}$ from the release point. The maximum distance at which the plume was detected was at Kingstree, South Carolina, $174 \mathrm{~km}$ from the release point at $6: 00 \mathrm{p} . \mathrm{m}$. The tritium oxide concentration observed was approximately $9500 \mathrm{pCi} / \mathrm{m}^{3}$. Thirty minutes later, the tritium oxide concentration had dropped to $100 \mathrm{pCi} / \mathrm{m}^{3}$ indicating the short time in which a person was exposed to the highest concentration within the plume. 


\section{TABLE 5}

\section{Tritium Trajectory Concentration Data Ground Level}

\begin{tabular}{|c|c|c|c|c|}
\hline $\begin{array}{l}\text { Sampler } \\
\text { No. }\end{array}$ & Location & $\begin{array}{l}\text { Time } \\
\text { on, p.m. }\end{array}$ & $\begin{array}{l}\text { HTO Data } \\
\mathrm{pCi} / \mathrm{m}^{3}\end{array}$ & $\begin{array}{l}\mathrm{HT} \text { Data } \\
\mathrm{pCi} / \mathrm{m}^{3}\end{array}$ \\
\hline $\begin{array}{l}1 \\
2\end{array}$ & $\begin{array}{l}\text { Barnwell Barricade } \\
\text { Norway }\end{array}$ & $\begin{array}{r}12: 50 \\
2: 04\end{array}$ & $\begin{array}{r}3603.5 \\
80019.1\end{array}$ & $\begin{array}{l}25.1 \\
28.6\end{array}$ \\
\hline $\begin{array}{l}3 \\
4 \\
5\end{array}$ & $\begin{array}{l}\text { Orangeburg at Cope } \\
\text { St. Matthews } \\
\text { Creston }\end{array}$ & $\begin{array}{l}1: 50 \\
3: 16 \\
3: 49\end{array}$ & $\begin{array}{r}112.9 \\
28.7 \\
2022.6\end{array}$ & $\begin{array}{r}29.6 \\
.6 \\
47.5\end{array}$ \\
\hline $\begin{array}{l}6 \\
7 \\
8\end{array}$ & 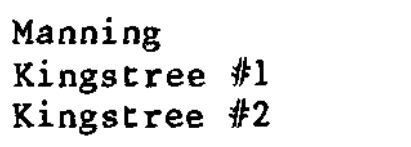 & $\begin{array}{l}4: 55 \\
6: 00 \\
6: 30\end{array}$ & $\begin{array}{r}521.4 \\
9498.6 \\
103.5\end{array}$ & $\begin{array}{r}4.7 \\
25.2 \\
12.5\end{array}$ \\
\hline $\begin{array}{r}9 \\
10 \\
11\end{array}$ & $\begin{array}{l}\text { Lake City } \\
\text { Gourdin } \\
\text { Santee }\end{array}$ & $\begin{array}{l}7: 38 \\
7: 37 \\
9: 00\end{array}$ & $\begin{array}{l}245.7 \\
456.6 \\
437.7\end{array}$ & $\begin{array}{r}17.8 \\
6.8 \\
2.7\end{array}$ \\
\hline 12 & $I-95$ & $9: 00$ & 198.2 & 52.7 \\
\hline
\end{tabular}

\section{Bioassay Results}

Urine samples were collected from 75 people located in or near the predicted path of the release and analyzed for tritium. The maximum dose commitment from these measurements was $0.2 \mathrm{mrem}$.

Tritium concentrations from $0.002 \mu \mathrm{Ci} / \mathrm{L}$ to $0.021 \mu \mathrm{Ci} / \mathrm{L}$ of urine were measured in samples submitted by 22 individuals residing in the path of the release. The dose commitment for these 22 people ranged from 0.01 to $0.2 \mathrm{mrem}$. Urinalys is data from 49 other individuals show that their exposure was less than 0.01 mrem.

The average dose commitment for persons within $1.5 \mathrm{~km}$ of the predicted centerline of the cloud path was

- 0.09 mrem for six individuals within $1.5 \mathrm{~km}$ of the plant boundary;

- 0.05 mrem for seven individuals from 7 to $8 \mathrm{~km}$ from plant;

- 0.02 mrem for five individuals from 8 to $16 \mathrm{~km}$ from the plant;

- 0.01 mrem for twelve individuals that were greater than $16 \mathrm{~km}$ from the plant. 
The average dose commitment for persons that were more than $15 \mathrm{~km}$ either side of the predicted center line was less than that observed along the center line with two exceptions:

1) One individual with a dose commitment of 0.04 mrem residing $5 \mathrm{~km}$ north of the line;

2) One person in Blackville with a dose commitment of 0.12 mrem.

The predicted trajectory and area from which samples were collected are shown in Figure 5. The detailed data from urinalyses of people both downwind of H-Area and upwind of H-Area on March 27, 1981 are presented in Appendix A.

\section{Final Bstimate of Offsice Radiation Exposure}

\section{Analyzed Trajectory}

Figure 6 shows the final estimate of the release rrajectory, based on analysis of all National Weather Service (NWS) and SRP wind observations. This trajectory was derived from a subjective analysis of the observed data and was later confirmed by a JEREMIAH calculation in which the winds were analyzed by using an objective analysis scheme. The analysis is straightforward to a distance of about $160 \mathrm{~km}$, which is near Kingstree, South Carolina. At that point, winds at $10 \mathrm{~m}$ elevations were dropping as surface cooling after sunset rapidly decreased atmospheric turbulence and the downward transport of momentum. Winds above the first $100 \mathrm{~m}$ remained as high or higher than they were during the day. Based on the observed maximum mixed layer depth of $2400 \mathrm{~m}$ at Charleston for March 27, and the expected uniform distribution of tritium within the mixed layer, it is inferred that most of the release continued to the east at a speed of about $7 \mathrm{~m} / \mathrm{s}$. The percentage of tritium that continued to move eastward was approximately $2300 / 2400=95 \%$, since this is the part that was above the 100 m deep surface layer. This inference is also supported by the behavior of the winds from $10 \mathrm{~m}$ up to $300 \mathrm{~m}$ at the instrumented WJBF-TV tower near SRP, which were probably representative of the entire region, given the uniform conditions on March 27. The remaining $5 \%$ of the tritium that was trapped in the surface layer moved slowly northeast until the cold front arrived in the area at about 9:00 p.m. After that, the cool, but turbulent air behind the front mixed with the cool, nonturbulent air of the surface layer and carried the tritium in the surface layer southward and off the coast by about 2:00 a.m. on March 28. The tritium that was above the surface layer would not have been significantly affected by the front because the air behind the front was colder than the air containing the elevated portion of the tritium. The resulting stably stcatified air mass most likely retarded turbulent mixing between the two layers. 


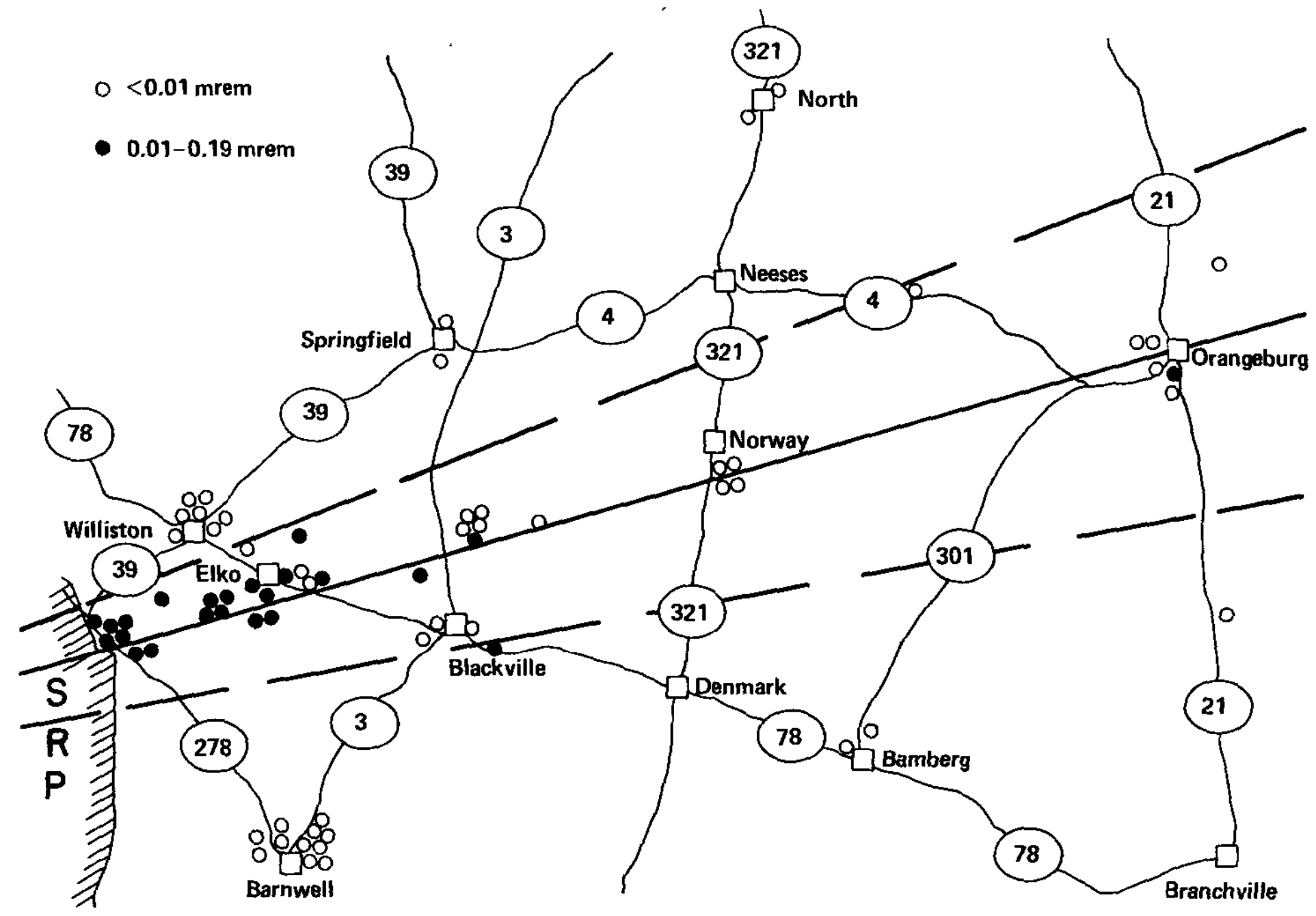

FIGURE 5. Dose Commitment to Persons Downwind From Tritium Release on $3 / 27 / 81$ 


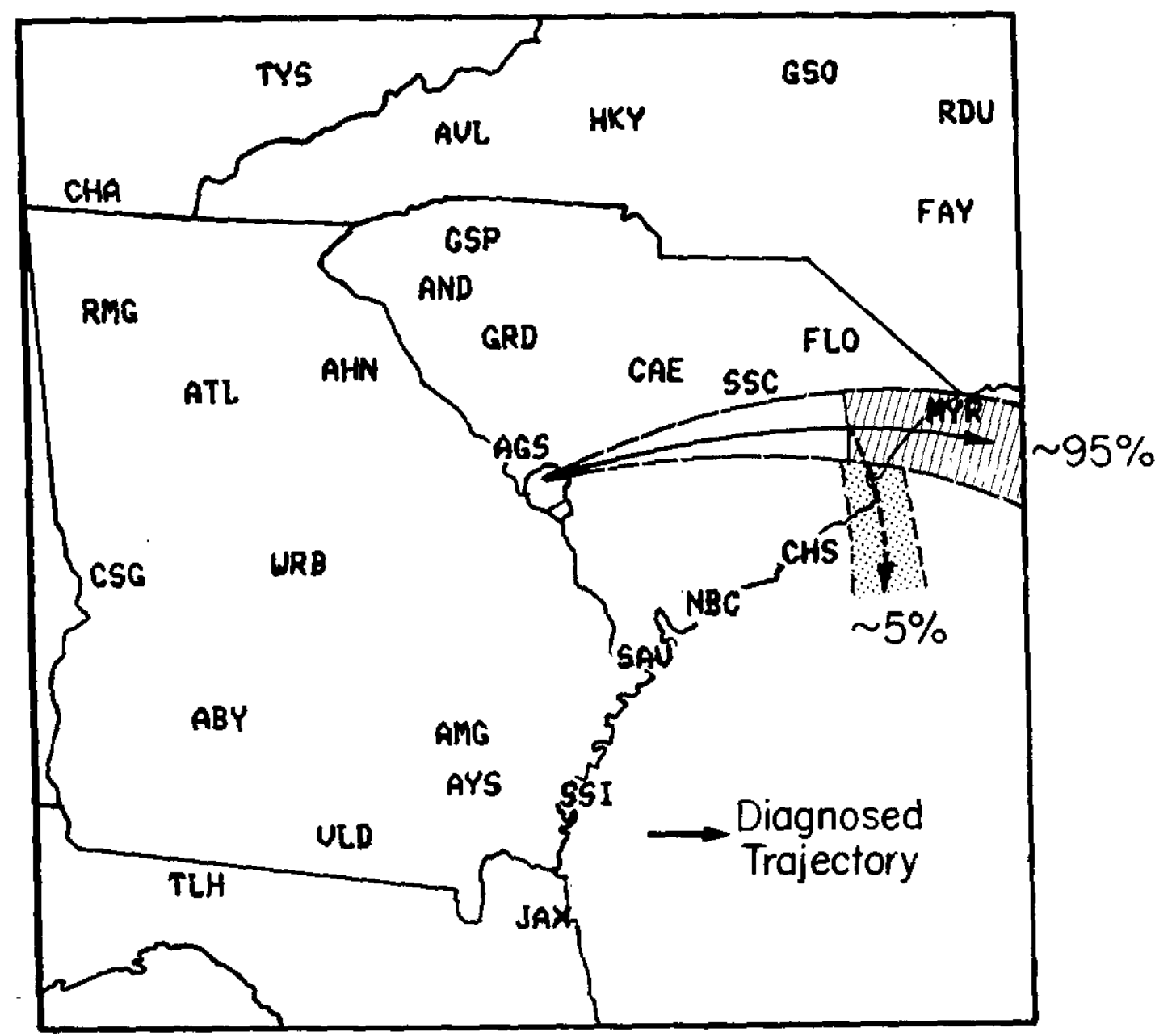

FIGURE 6. Best Bstimate of Trajectory 
Accordingly, Figure 6 shows the major part of the release continuing to the east and off the coast near Myrtle Beach at approximately 2:00 a.m. and the surface remant moving sourh with the cold front.

The only quantitative information on the width of the tritium plume comes from tritium concentrations in pine needles that were taken at eight locations along Highway 8 of SRP. This road was nearly perpendicular $=0$ the plume rrack (Figure 3) and about $13 \mathrm{~km}$ from $H$ Area at the point the tritium crossed it. The activity in che needles defined the plume width with some precision (Figure 7), and the predicted plume width from both the WIND and JEREMIAH predictions was in reasonable agreement. Note that a shift in wind direction of $8.0^{\circ}$ causes the plume width and location calculated by JEREMIAH to agree closely with that determined from the analysis of the pine needles. At best, the mean wind direction can only be determined to within $\pm 5^{\circ}$, so the agreement between observation and prediction in Figure 7 is close to maximum achievable accuracy.

The detailed trajectory as depicted in Figure 6 can be used to deduce the position of the plume relative to the air samplers, while they were in operation (see Table 6). All of the samples except the one from St. Matthews had tritium concentrations that were well above the background level of about $10 \mathrm{pCi} / \mathrm{m}^{3}$. Some of these samples caught the fringes of the plume, but missed the higher ground level concentrations near the center of the plume.

\section{TABLE 6}

\section{Plume Position Relative to Air Samplers}

\begin{tabular}{|c|c|c|c|}
\hline $\begin{array}{l}\text { Location of } \\
\text { Sampler }\end{array}$ & $\begin{array}{l}\text { Beginning } \\
\text { Time, p-m. }\end{array}$ & $\begin{array}{l}\text { Distance, } \\
\mathrm{km}\end{array}$ & $\begin{array}{l}\text { Relat ive } \\
\text { Plume Position }\end{array}$ \\
\hline Barnwell Barricade & $12: 50$ & 16 & Past Sampler \\
\hline Norway & $2: 04$ & 51 & Close to Sampler \\
\hline Orangeburg & $1: 50$ & 73 & North of Sampler \\
\hline St. Matthews & $3: 16$ & 89 & South of Sampler \\
\hline Creston & $3: 49$ & 94 & Close to Sampler \\
\hline Manning & $4: 55$ & 141 & Close to Sampler \\
\hline Gourdin & $7: 35$ & 165 & Past Sampler \\
\hline Kingstree 非 & $6: 00$ & 174 & Close to Sampler \\
\hline Kingstree $\# 2$ & $6: 30$ & 174 & Past Sampler \\
\hline Lake City & $7: 38$ & 184 & Past Sampler \\
\hline
\end{tabular}




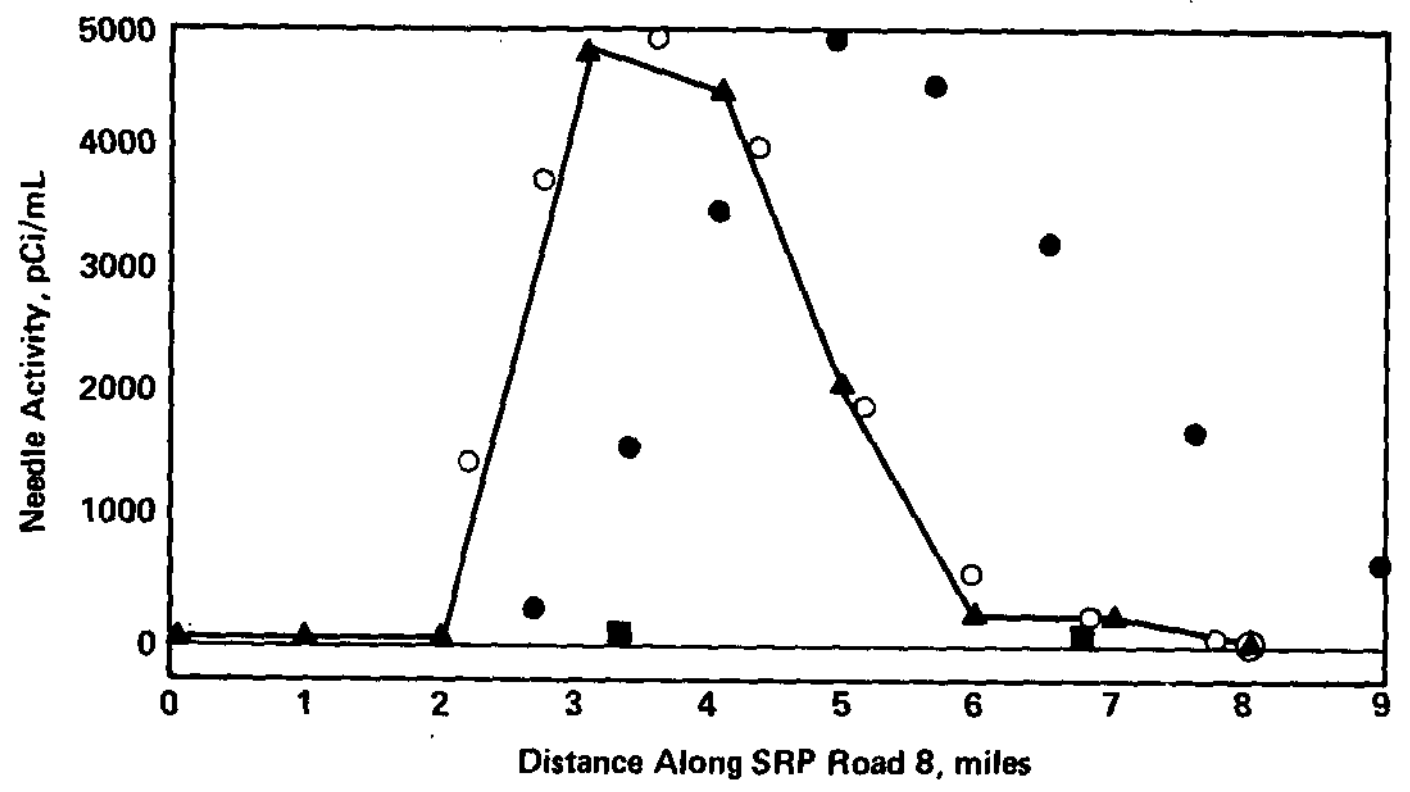

$\triangle$ MEASURED Activity of pine needles.

- WIND Calculation - $10 \%$ of centerline concentration.

- JEREMIAH Calculation - scaled to $5000 \mathrm{pCi} / \mathrm{mL}$.

O JEREMIAH Calculation - wind direction shifted $8.3^{\circ}$ scaled to $5000 \mathrm{pCi} / \mathrm{mL}$.

(2) Intersection of SRP Road 8 and US 278.

PIGURB 7. Comparison of Measured and Calculated Plume Shapes Along SRP Road 8 
Because there was no direct feedback from the field crews as to the level of the measurements, the uncertainty in the positioning and timing of the samples grew with distance from SRP. The high concentration that was measured at Kingstree at 6:00 p.m. shows that ESD personnel were accurately predicting the plume movement at distances of more than $160 \mathrm{~km}$ from SRP.

The rrajectory generated by the ARAC code ADPIC shows good agreement with the diagnosed trajectory (Figure 8). The ADPIC trajectory only extends to the Orangeburg, South Carolina area (about $70 \mathrm{~km}$ out), so the more complex part of the trajectory past Kingstree cannot be compared to the ADPIC calculation.

\section{Final Concentration Batimates}

Refining the plant boundary concentration and dose calculations was appropriate for two reasons:

1) A maximum mixed-1 ayer depth of $2400 \mathrm{~m}$ was derived from the 7:00 p.m. Charleston sounding. Forecast mixed-layer depths were not available earlier on March 27, because the 7:00 a.m. Athens, Georgia and Charleston, South Carolina rawinsonde data were not transmitted to SRP on the morning of the release. Climatological values for mixed-layer depth were used in the calculations that were made on March 27. The maximum climatological mixedlayer depth in the WIND code is $1000 \mathrm{~m}$.

2) The stability parameters used for the first hour of plume movement are critical to the plant boundary dose estimate. The values of $\sigma_{a}$ and $\sigma_{e}$ derived from the H-Area meteorological tower data for that hour were 14.3 and 8.5 , respectively. These values indicated neutral stability, rather than the unstable conditions which are expected on sunny days. Although instrumentation errors may be responsible, it is more probable that the morning surface temperature inversion was just breaking at H-Area. It is clear that the atmosphere was more unstable over the plant as a whole, and that plant averaged stability parameters are a better approximation to conditions within the tritium plume, except perhaps for the immediate vicinity of the release point.

Figure 9 compares measurements of tritium from air, soil, vegetation and surface water samples to calculations from the WIND system by using averaged meteorological data for all of SRP and mixed layer depths based on the observed maximum depth at Charleston. The estimates from the soil, vegetation, and water samples vary over a fairly wide range, because the observed concentrations had to be extrapolated back in time to give a maximum air 


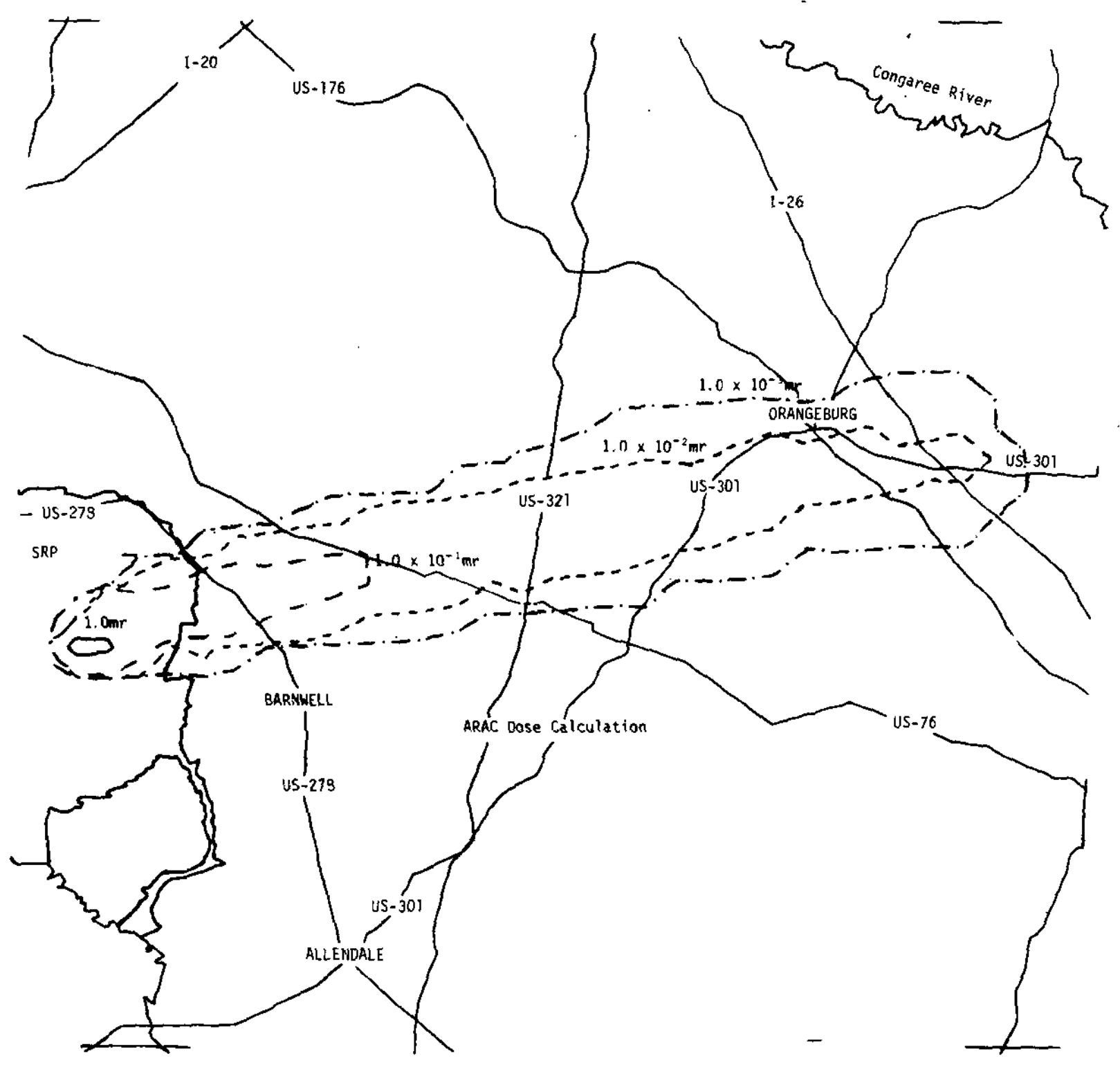

FIGURE 8. ARAC Dose Calculation 


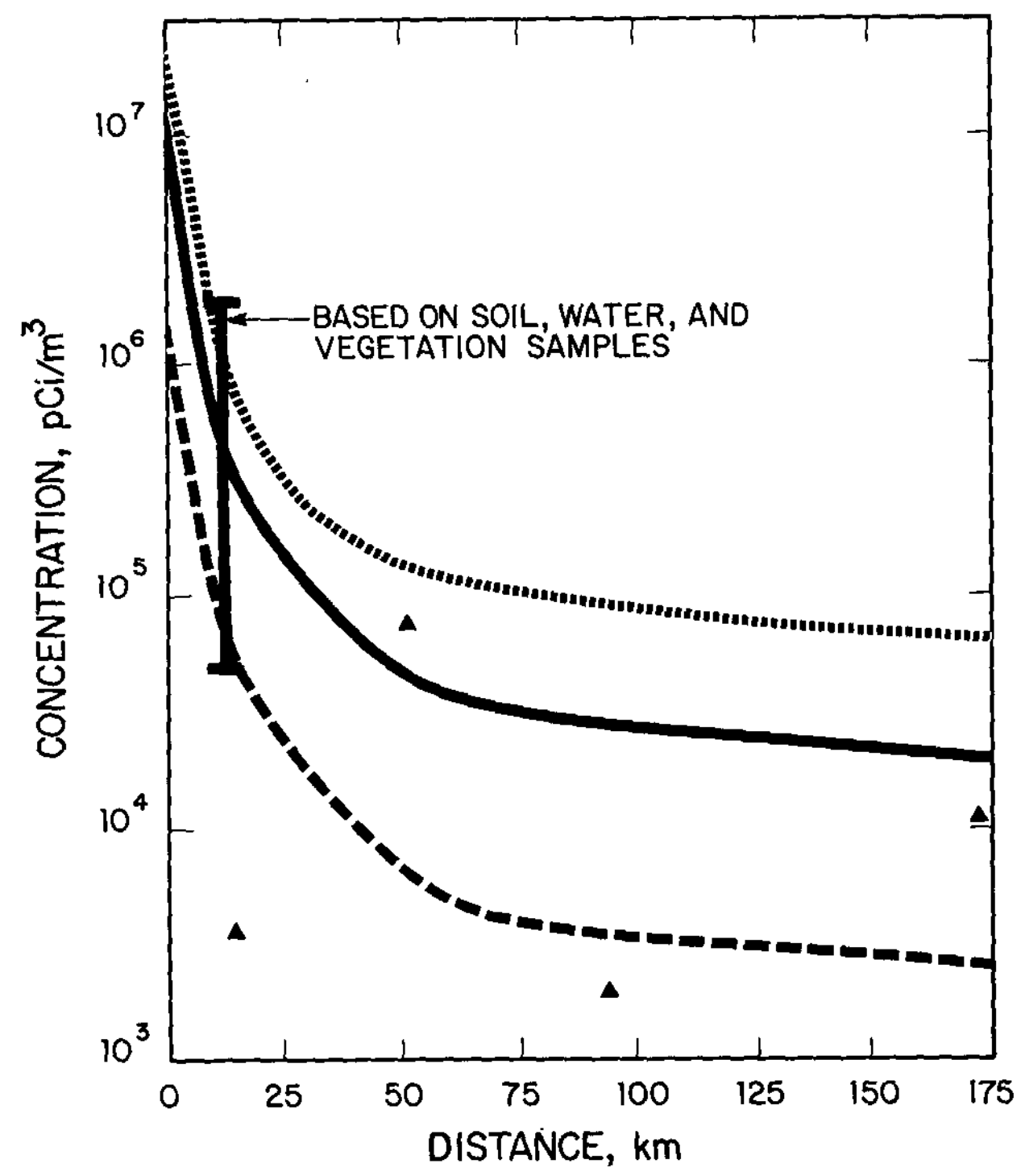

Centerline for 120-Minute Release

- - Plume Edge for 120-Minute Release

......... Centerline for 30-Minute Maximum Release

- Measured Concentrations

FIGURE 9. Observed and Calculated Air Concentrations 
concentration (see Appendix B). The error bars in Figure 9 delineate the range of estimates from the soil, vegetation, and water samples. The other observed data were derived from $30 \mathrm{~min}$ average air samples, and the extreme variations in concentrations from place to place were caused by sampling at different distances from the center of the plume. Some samples caught only the fringes of the plume. The three calculated curves encompass the entire range of expected concentrations within the HTO plume for averaging intervals of $30 \mathrm{~min}$ or more.

Two separate calculations were carried out, the first of which assumed that the $33,000 \mathrm{Ci}$ of HTO was released uniformly over a 2-hr period, and the second considered only the $23,750 \mathrm{Ci}$ of HTO that was released from 10:15 a.m. to 10:45 a.m. A downwind sampler which happened to be on during the 30-min period when the concentrated release passed through would have measured higher concentrations than expected, based on the 120-nin WIND calculation. The 30 -min calculation was added to Figure 9 to provide for the possibility that such a sample was actually taken. Apparently, the sample from Norway came from air within the concentrated part of the plume because the measured value of $80,000 \mathrm{pCi} / \mathrm{m}^{3}$ falls between the centerline maximum curve for the $120 \mathrm{~min}$ and the $30 \mathrm{~min}$ calculation. The Kingstree air sample, taken at a distance of $175 \mathrm{~km}$ also falls within the range of predicted concentrations. However, the simple atmospheric model contained within the WIND code is not adequate for such large downwind distances, so the Kingstree air sample should not be interpreted as a quanticative validation of the WIND atmospheric model. It does suggest that simple atmospheric transport and diffusion models have some applicability to larger downwind distances in cases of uniform meteorological conditions.

The JEREMLAH atmospheric transport and diffusion code also calculated HTO concentrations in air near ground level at the eight offsite sampling locations. These results are shown in Figure 10, both for the calculation with actual mean measured winds of March 27 and the calculation in which the wind direction was shifted by $8^{\circ}$ (see "Analyzed Trajectory" of this report). These calculations display general agreement with the corresponding 30-min measured air concentrations. As was the case in the comparisons of the pine needle activity with the calculations, the $8^{\circ}$ wind direction shift improved the overall agreement for most of the measurements. However, there were discrepancies, such as at Norway, where the measured concentration was close to the calculated maximum, but occurred about an hour later than predicted. This discrepancy probably can be attributed to the low elevation of the measurements, which are biased upward after cloud passage by the rritium trapped in the low wind-speed zone near the ground. The other samples show that the plume was about where it was predicted to be, although the concentrations are of $f$ by an order of 

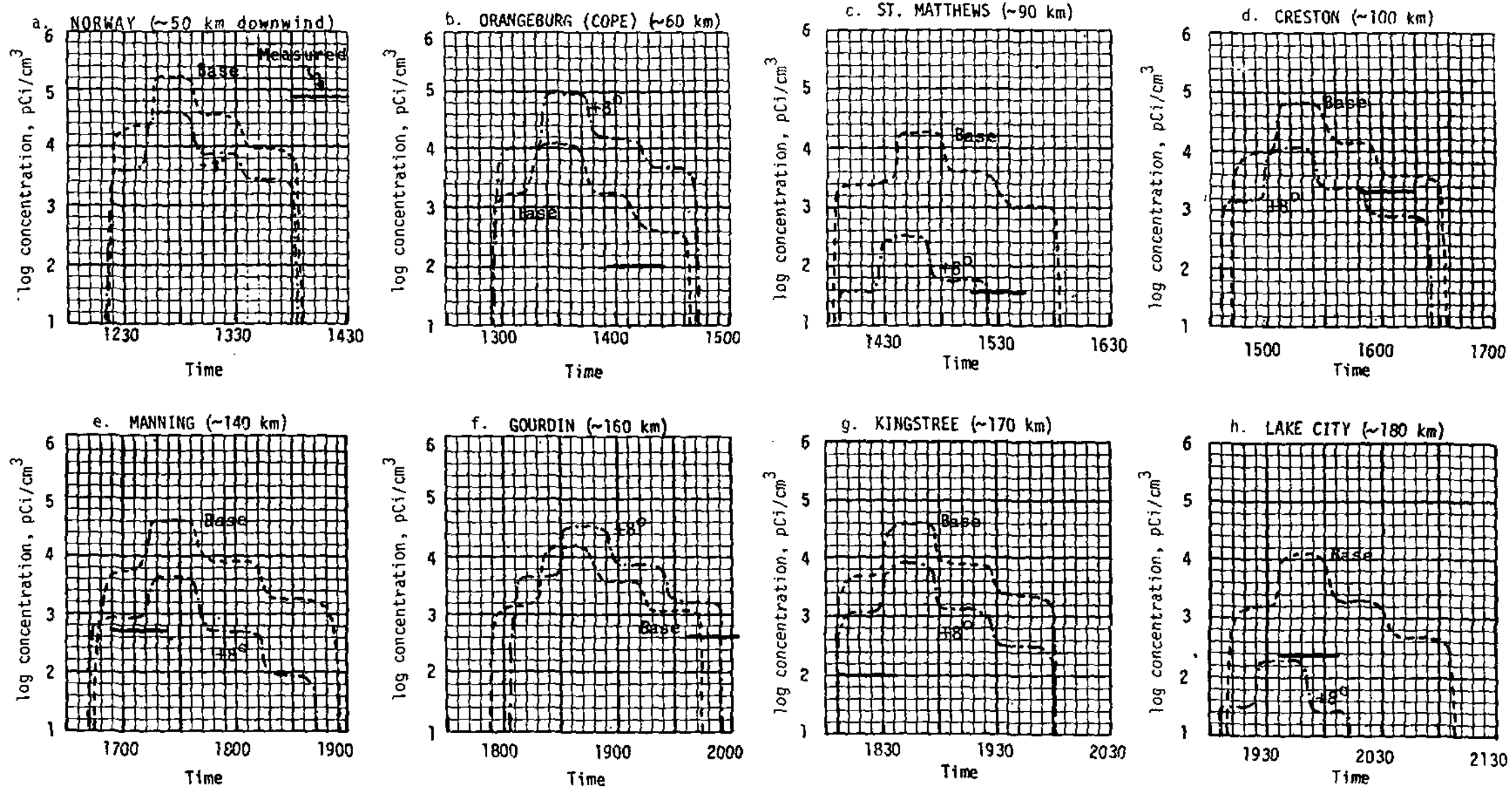

FIGURE 10. Couparison of Measured and Calculated Air Concentrations 
magnitude or more in two cases. These errors in predicted concentrations were at least partly caused by departures of the real plume from the idealized Gausian profile.

\section{Maximum Individual Dose}

The plant boundary dose calculaced by the WIND code for a uniform $120-\mathrm{min}$ release of $33,000 \mathrm{Ci}$ of HTO, and for four 30 -min releases of $2800,23,750,4890$, and $1560 \mathrm{Ci}$ is about $0.3 \mathrm{mrem}$ in both cases. The maximum individual dose is also confirmed by the JEREMIAH calculations. The distance from $\mathrm{H}$ Area to the plant boundary along the cloud track is about $16 \mathrm{~km}$. This dose is supported not only by the air, water, soil, and vegetation samples discussed earlier but also by bioassays of urine samples which verified doses of up to about 0.2 mrem for a few individuals who were east of SRP on March 27. To summarize, several independent and fundamentally different types of measurements support the calculated 0.3 mrem plant boundary dose, which was derived solely from the meteorological and source term data.

\section{Offrite Population Dose}

The population dose was calculated to be 4 man-rem by using the JEREMIAH calculational system. The transport and dispersion of HTO was calculated by using a Gaussian segmented plume model (ADPLUM). This calculation produced ground level concentratins of HTO integrated over time in each of 1024 grid blocks (a square array of 32 grids block on a side). The integrated concentrations are in units of $(\mathrm{Ci}-\mathrm{sec}) / \mathrm{m}^{3}$.

The population dose was then calculated by summing the product of the integrated ground level concentration in each grid block and the population of each grid block over all grid blocks and multiplying the resulting sum by the dose conversion factor for HTO. The population distribution used in the calculations is based on the 1970 Census, because detailed population distributions from the 1980 Census are not yet available. However, the total population of South Carolina increased 18.4\% from 1970 to 1980. Thus, the population dose calculated by using populations based on 1970 Census results was multiplied by 1.20 to account for the increase in population since 1970. 


\section{HEALTH EFPECTS CONSIDERATIONS}

\section{Comparison with Previous Releases}

Two comparable tritium releases 7,8 occurred previously at SRP on May 2, 1974 and on December 31, 1975. Table 7 summarizes the parameters for the March 27, 1981 release and the two previous releases and gives the calculated doses.

\section{Comparison with other Radiation Sources}

A comparison of the health effects of the March 27, 1981 release with the dose due to all SRP releases during 1980 and also due to other sources of radiation is shown in Table 8 . The maximum dose received by an individual in the public zone $(0.3 \mathrm{mrem})$ was less than $0.2 \%$ of the dose received annually from natural background radiation, medical, and miscellaneous sources of radiation. Therefore, the public health consequences of the release were insignificant.

\section{TABLE 7}

Comparison of March 27, 1981 Tritium Release to Barlier Releass

\begin{tabular}{|c|c|c|c|}
\hline & Date of & & \\
\hline & $5 / 04 / 74 x$ & $12 / 31 / 75$ & $3 / 27 / 81$ \\
\hline Total Curies of Tritium & 479,000 & 182,000 & 33,000 \\
\hline Percent HTO & 1 & 0.6 & 99 \\
\hline Total Curies of Oxide & $\begin{array}{l}960 * * \\
4800 * * *\end{array}$ & 1,000 & 32,700 \\
\hline $\begin{array}{l}\text { Maximum Individual Dose } \\
\text { at Plant Boundary, mrem }\end{array}$ & 0.018 & 0.014 & 0.3 \\
\hline Population Dose, man-rem & 8 & 0.2 & 4 \\
\hline
\end{tabular}

\footnotetext{
* See Appendix A, Reference 8.

** $960 \mathrm{Ci}$ HTO assumed for plant boundary dose calculation.

*** $4800 \mathrm{Ci}$ HTO assumed for total population dose estimate.
} 
TABLE 8

Comparison of Health Effects

Radiation Source

SRP Tritium Release

(March 27, 1981)

- Calculated

- Maximum Observed By Urinalys is

- SRP 1980 Releases

(A11 Nuclides)

Narural Background Sources**

Medical X-Rays**

Weapons Test Fallout**

Miscellaneous Sources of

Radiation**

* Maximum Individual

** Average Individual - Yearly
Dose to

Individual, mrem

$0.3 *$

0.2

$1.3 *$

93

91

5

5 


\section{LIST OF REFERENCES}

1. Environmental Monitoring in the Vicinity of the Savannah River Plant - Annual Report for 1980. USDOE Report DPSPU-81-30-1 E. I. du Pont de Nemours \& Co., Savannah River Plant, Aiken, SC (1981).

2. T. B. Rhinehammer and P. H. Lamberger. Tritium Control Technology, USAEC Report WASH-1269, Monsanto Research Corp., Mound Laboratory, Miamisburg, OH (1973).

3. Tritium in the Environment. National Council on Radiation Protection and Measurements, No. 62, Washington, DC (1979).

4. R. V. Osborne. "Absorption of Tritiated Water Vapor by People." Healkh Phys 12, 1527 (1966).

5. H. L. Butler. "Observation of Biological Half-Life of Tritium." Health Physics 11, 1 (1965).

6. Limits for Intakes of Radionuclides by Workers. International Commission on Radiation Protection, Publication 30, part $\tau$ Pergamon Press, New York, NY (1979).

7. W. L. Marter. Environmental Effects of a Tritium Gas Release from the Savannah River Plant on May 2, 1974. USAEC Report $\overline{D P}-1369$, E. I. du Pont de Nemours \& Co., Savannah River Laboratory, Aiken, SC (November 1974).

8. W. R. Jacobsen. Environmental Effects of a Tritium Gas Release from the Savannah River Plant on December 31, 1975 . USERDA Report DP-1415, E. I. du Pont de Nemours \& Co., Savannah River Laboratory, Aiken, SC (March 1976). 
APPBNDIX A

APPBNDIX A

URINALYSIS DATA

ri

$-32-$ 
TABLE A. 1

Tritium Urinalysis Data for Members of Employees Household Downwind From H Area on 3/27/81

\begin{tabular}{|c|c|c|c|c|c|}
\hline $\begin{array}{l}\text { Sample } \\
\text { No. }\end{array}$ & Location & $\begin{array}{l}{ }^{3} \mathrm{H} \text { Conc. } \\
\text { in Urine } \\
\mu \mathrm{Ci} / \mathrm{L}\end{array}$ & Date & $\begin{array}{l}\text { Est. }{ }^{3} \mathrm{H} \text { Conc. } \\
\text { on } 3 / 27 \text {, } \\
\mu \mathrm{Ci} / \mathrm{L}\end{array}$ & $\begin{array}{l}\text { Dose } \\
\text { Commitment, } \\
\text { mrem }\end{array}$ \\
\hline 1 & Barnwel1 & 0.001 & $3 / 28$ & 0.001 & 0.007 \\
\hline 2 & Springfield & $<\mathrm{MDA}^{\star}$ & $3 / 28$ & - & $<0.01$ \\
\hline 4 & Orangeburg & $<\mathrm{MDA}$ & $3 / 28$ & - & $<0.01$ \\
\hline 5 & North & $<\mathrm{MDA}$ & $3 / 28$ & - & $<0.01$ \\
\hline 8 & Williston & $<\mathrm{MDA}$ & $3 / 28$ & - & $<0.01$ \\
\hline 9 & Williston & $<\mathrm{MDA}$ & $3 / 28$ & - & $<0.01$ \\
\hline 10 & Williston & 0.001 & $3 / 28$ & 0.001 & 0.007 \\
\hline 11 & Blackville & 0.054 & $3 / 29$ & 0.062 & - \\
\hline 12 & Bamberg & $<\mathrm{MDA}$ & $3 / 28$ & - & $<0.01$ \\
\hline 13 & Williston & $<\mathrm{MDA}$ & $3 / 28$ & - & $<0.01$ \\
\hline 16 & North & $<\mathrm{MDA}$ & $3 / 28$ & - & $<0.01$ \\
\hline 25 & Bamberg & $<\mathrm{MDA}$ & $3 / 28$ & - & $<0.01$ \\
\hline 27 & Springfield & 0.001 & $3 / 28$ & 0.001 & 0.007 \\
\hline 33 & Blackville & 0.002 & $3 / 28$ & 0.002 & 0.015 \\
\hline 34 & Blackville & $<\mathrm{MDA}$ & $3 / 28$ & - & $<0.01$ \\
\hline 35 & Blackville & $<\mathrm{MDA}$ & $3 / 28$ & - & $<0.01$ \\
\hline 36 & Blackville & \multicolumn{2}{|c|}{ ins. Samp**3/28 } & - & - \\
\hline 37 & Blackville & $<\mathrm{MDA}$ & $3 / 28$ & - & $<0.01$ \\
\hline 38 & Blackville & $<\mathrm{MDA}$ & $3 / 28$ & - & $<0.01$ \\
\hline 39 & Blackville & $<\mathrm{MDA}$ & $3 / 28$ & - & $<0.01$ \\
\hline 40 & Blackville & $<\mathrm{MDA}$ & $3 / 28$ & - & $<0.01$ \\
\hline 41 & Blackville & $<\mathrm{MDA}$ & $3 / 28$ & - & $<0.01$ \\
\hline 42 & Blackville & ins. Samp & $3 / 28$ & - & - \\
\hline 43 & Barnwell & $<\mathrm{MDA}$ & $3 / 29$ & - & $<0.01$ \\
\hline 45 & Barnwell & $<\mathrm{MDA}$ & $3 / 28$ & - & $<0.01$ \\
\hline 46 & Barnwell & 0.001 & $3 / 28$ & 0.001 & 0.007 \\
\hline
\end{tabular}

* $\angle \mathrm{MDA}=$ less than minimum detectable amount $(0.001 \mu \mathrm{Ci} / \mathrm{L})$

** Insufficient sample 
TABLE A.1 (cont)

\begin{tabular}{|c|c|c|c|c|c|}
\hline $\begin{array}{l}\text { Sample } \\
\text { No. } \\
\end{array}$ & Location & $\begin{array}{l}{ }^{3} \mathrm{H} \text { Conc. } \\
\text { in Urine } \\
\mu \mathrm{Ci} / \mathrm{L}\end{array}$ & Date & $\begin{array}{l}\text { Est. }{ }^{3} \mathrm{H} \text { Conc. } \\
\text { on } 3 / 27 \text {, } \\
\mu \mathrm{Ci} / \mathrm{L}\end{array}$ & $\begin{array}{l}\text { Dose } \\
\text { Commitment, } \\
\text { mrem }\end{array}$ \\
\hline 47 & Barnwell & $<\mathrm{MDA}$ & $3 / 28$ & - & $<0.01$ \\
\hline 48 & Barnwell & $<\mathrm{MDA}$ & $3 / 28$ & - & $<0.01$ \\
\hline 49 & Barnwell & $<\mathrm{MDA}$ & $3 / 28$ & - & $<0.01$ \\
\hline 50 & Barnwell & $<\mathrm{MDA}$ & $3 / 28$ & - & $<0.01$ \\
\hline 51 & Barnwe 11 & ins. Samp & $3 / 28$ & - & - \\
\hline 52 & Barnwell & $<\mathrm{MDA}$ & $3 / 28$ & - & $<0.01$ \\
\hline 53 & Barnwe 11 & $<\mathrm{MDA}$ & $3 / 28$ & - & $<0.01$ \\
\hline 54 & Williston & $<\mathrm{MDA}$ & $3 / 28$ & - & $<0.01$ \\
\hline 58 & Orangeburg & $<\mathrm{MDA}$ & $3 / 29$ & - & $<0.01$ \\
\hline 59 & Orangeburg & $<\mathrm{MDA}$ & $3 / 29$ & - & $<0.01$ \\
\hline 60 & Orangeburg & 0.001 & $3 / 29$ & 0.001 & 0.008 \\
\hline 61 & Orangeburg & $<\mathrm{MDA}$ & $3 / 29$ & - & $<0.01$ \\
\hline 64 & Blackville & 0.001 & $3 / 29$ & 0.00 & 0.008 \\
\hline 66 & Williston & $<\mathrm{MDA}$ & $3 / 28$ & - & $<0.01$ \\
\hline 67 & Williston & $<\mathrm{MDA}$ & $3 / 28$ & - & $<0.01$ \\
\hline 69 & Orangeburg & $<\mathrm{MDA}$ & $3 / 30$ & - & $<0.01$ \\
\hline 70 & Orangeburg & 0.002 & $3 / 30$ & 0.003 & 0.018 \\
\hline 75 & $\begin{array}{l}\text { Healing } \\
\text { Springs }\end{array}$ & 0.008 & $3 / 29$ & 0.009 & 0.067 \\
\hline 76 & Barnwell & 0.001 & $3 / 29$ & 0.001 & 0.008 \\
\hline 77 & Williston & $<\mathrm{MDA}$ & $3 / 31$ & - & $<0.01$ \\
\hline 78 & Blackville & 0.013 & $3 / 31$ & 0.017 & 0.124 \\
\hline 79 & Williston & 0.005 & $3 / 30$ & 0.006 & 0.045 \\
\hline 80 & Williston & 0.005 & $3 / 31$ & 0.007 & 0.048 \\
\hline 81 & Elko & 0.007 & $3 / 29$ & 0.008 & 0.058 \\
\hline 82 & Baces. Cem. & 0.002 & $3 / 30$ & 0.003 & 0.018 \\
\hline 83 & Greer Acad. & 0.006 & $3 / 30$ & 0.007 & 0.054 \\
\hline 84 & Greer Acad. & 0.006 & $3 / 30$ & 0.007 & 0.054 \\
\hline 85 & Williston & 0.002 & $3 / 30$ & 0.003 & 0.018 \\
\hline 86 & Williston & 0.003 & $3 / 30$ & 0.004 & 0.027 \\
\hline
\end{tabular}


TABLE A.1 (cont)

\begin{tabular}{|c|c|c|c|c|c|}
\hline $\begin{array}{l}\text { Samp le } \\
\text { No. } \\
\end{array}$ & Location & $\begin{array}{l}{ }^{3} \mathrm{H} \text { Conc. } \\
\text { in Urine } \\
\mu \mathrm{Ci} / \mathrm{L}\end{array}$ & Date & $\begin{array}{l}\text { Est. }{ }^{3} \mathrm{H} \text { Conc. } \\
\text { on } 3 / 27, \\
\mu \mathrm{Ci} / \mathrm{L}\end{array}$ & $\begin{array}{l}\text { Dose } \\
\text { Commitment, } \\
\text { mrem }\end{array}$ \\
\hline 87 & Williston & 0.003 & $3 / 30$ & 0.004 & 0.027 \\
\hline 88 & Williston & 0.021 & $3 / 30$ & 0.026 & 0.190 \\
\hline 92 & Dark Horse & 0.011 & $3 / 31$ & 0.014 & 0.106 \\
\hline 93 & Dark Horse & 0.010 & $3 / 30$ & 0.012 & 0.090 \\
\hline 94 & Dark Horse & 0.011 & $3 / 30$ & 0.014 & 0.098 \\
\hline 95 & Dark Horse & 0.013 & $3 / 30$ & 0.016 & 0.117 \\
\hline 96 & Elko & 0.001 & $3 / 31$ & 0.001 & 0.009 \\
\hline 97 & Elko & 0.002 & $3 / 31$ & 0.003 & 0.019 \\
\hline 98 & Elko & 0.001 & $3 / 31$ & 0.001 & 0.009 \\
\hline 99 & Norway & 0.001 & $3 / 31$ & 0.001 & 0.009 \\
\hline 100 & Norway & $<\mathrm{MDA}$ & $3 / 31$ & - & $<0.01$ \\
\hline 101 & Williston & 0.002 & $3 / 30$ & 0.003 & 0.018 \\
\hline 102 & Williston & 0.005 & $3 / 30$ & 0.006 & 0.045 \\
\hline 103 & Elko & 0.001 & $3 / 31$ & 0.001 & 0.009 \\
\hline 104 & Elko & 0.002 & $3 / 31$ & 0.003 & 0.019 \\
\hline 105 & Norway & 0.001 & $3 / 31$ & 0.001 & 0.009 \\
\hline 106 & Norway & 0.001 & $3 / 31$ & 0.001 & 0.009 \\
\hline 107 & Barnwell & $<\mathrm{MDA}$ & $3 / 31$ & - & $<0.01$ \\
\hline 108 & Neeses & $<\mathrm{MDA}$ & $3 / 31$ & - & $<0.01$ \\
\hline
\end{tabular}


TABLB A. 2

Tritiun Urinalysis Data for Members of Employee's Household Upwind From B Area On 3/27/81

\begin{tabular}{|c|c|c|}
\hline $\begin{array}{l}\text { Sample } \\
\text { No. } \\
\end{array}$ & Location & $\begin{array}{l}{ }^{3} \mathrm{H} \text { Conc. } \\
\text { in Urine } \\
\mu \mathrm{Ci} / \mathrm{L}\end{array}$ \\
\hline 7 & Jackson, sc & 0.001 \\
\hline 17 & Aiken, SC & ins. samp \\
\hline 24 & Evans, GA & $<\mathrm{MDA}$ \\
\hline 26 & New Ellenton, SC & 0.003 \\
\hline 55 & Aiken, SC & $<\mathrm{MDA}$ \\
\hline 56 & Aiken, SC & $<\mathrm{MDA}$ \\
\hline 57 & Aiken, SC & $<\mathrm{MDA}$ \\
\hline 65 & New Ellenton, SC & $<\mathrm{MDA}$ \\
\hline
\end{tabular}




\section{CALCULATION OP ATMOSPHERIC TRITIUM CONCENTRATION FROM TRITIUM LEVELS IN VEGETATION, SOIL, AND SURPACE WATER}

Atmospheric tritium concentrations can be calculated from vegetation tritium levels based on the known exchange characteris$t i c s$ of pine needles and the $t$ ime elapsed between plume passage and sampling. A value of $2 \times 10^{6} \mathrm{pCi} / \mathrm{m}^{3}$ was estimated in this way. However, due to uncertainties in the parameters used in this calculation and the rapid exchange of HTO in pine needles, possible values range from $10^{7}$ to $10^{5} \mathrm{pCi} / \mathrm{m}^{3}$. Estimates of atmospheric tritium can also be made by using the tritium levels found in pine litter water and surface water from known deposition velocities for HTO vapor and the $t$ ime for plume passage ( $30 \mathrm{~min}$ ). Calculations from the pine litter data give an estimate between $5 \times 10^{4}$ and $2 \times$ $10^{5} \mathrm{pCi} / \mathrm{m}^{3}$. Similar calculations from surface water tritium levels yield an estimate of between $2 \times 10^{5}$ and $8 \times 10^{5} \mathrm{pCi} / \mathrm{m}^{3}$. The estimates of atmospheric tritium concentration calculated from tritium in vegetation, soil, and surface water agree reasonably well with the computer estimate of the peak release concentration at a distance of $12 \mathrm{~km}\left(5 \times 10^{5} \mathrm{pCi} / \mathrm{m}^{3}\right)$. However, the wide range of estimates from these calculations indicate that these data are more useful in delineating the extent of contamination rather than in estimating atmospheric tritium levels during plume passage. 
The environmental analysis of the March 27, 1981 tritium release was the combined effort of several groups within the HP Department of SRP and ESD of SRL. The authors wish to acknowledge the major contributions of the following individuals from these groups:

C. Ashley

C. E. Bailey

A. L. Boni

P. A. Culp

R. M. Hall

C. E. Murphy

C. W. Sweet 